\title{
Review: New Zealand Geology
}

Author(s): J. W. G.

Review by: J. W. G.

Source: The Geographical Journal, Vol. 42, No. 4 (Oct., 1913), pp. 391-392

Published by: geographicalj

Stable URL: http://www.jstor.org/stable/1779075

Accessed: 27-04-2016 08:10 UTC

Your use of the JSTOR archive indicates your acceptance of the Terms \& Conditions of Use, available at

http://about.jstor.org/terms

JSTOR is a not-for-profit service that helps scholars, researchers, and students discover, use, and build upon a wide range of content in a trusted digital archive. We use information technology and tools to increase productivity and facilitate new forms of scholarship. For more information about JSTOR, please contact support@jstor.org.

The Royal Geographical Society (with the Institute of British Geographers), Wiley are collaborating with JSTOR to digitize, preserve and extend access to The Geographical Journal 
pessimistically of his adopted land. Immense water-power and vast pulp lands are yet entirely undeveloped, the waste products of the fisheries will be utilized and cold sturage introduced to improve the value of the exports. The farming of fur-bearing animals is beginning, and should prove highly remunerative, while every year prospectors are seeking for gold, though its discovery might be a doubtful blessing to Labrador.

Panama Canal. What it is and what it means. By John Barrett. (Washington: Pan-American Union. 1913. Pp. 120. Maps and Illustrations. \$1. This is a useful little handbook to the isthmus of Panama and the canal designed for tourists and others who desire condensed information on the subject. Mr. Barrett, who has had extensive experience as United States Minister to various American lands and is now Director-General of the PanAmerican Union, writes with unalloyed enthusiasm not only of the canal and its future, but what he is pleased to describe as "Uncle Sam's work" in the canal zone. He wants " the tropics and Panama to get a square deal," and he believes the completion of the canal will signalize the opening of a Pan-American era. The style is vivacious if a little egotistical, and includes a liberal allowance of American slang, such as "insect devil" and "malarial-bearing bird" as synonymous with mosquito, and expressions such as "quite a little east of south ; " but why should Vasco Nuñez de Balboa be modernized to the extent of being referred to as Mr. Balboa? There are many good illustrations, but it is unfortunate that the maps to show the relations of the canal to trade routes should have been drawn on Mercator's projection. The bibliography is almost exclusively of American books.

\section{AUSTRALASIA AND PACIFIC ISLANDS.}

New Zealand Geology.

'Geology of New Zealand.' By P. Marshall. Wellington: 1912. Pp. viii., 218. Map, 112 Figs.

The 'Geology of New Zealand,' by Prof. P. Marshall, is mainly a synopsis of the principles of geology, especially on its geographical side, as illustrated by New Zealand examples. It should, therefore, prove to students in New Zealand a most valuable supplement to the standard text-books. It may also be read with profit outside that country, owing to its statements by one of the ablest of New Zealand geologists as to the applicability of current theories to the local evidence. The book gives no references to literature, and mentions very few authorities, while the section on the historical geology of the country, which to readers outside New Zealand would be of most interest, is very brief. The book is therefore written on very different lines from Prof. Park's text-book. One striking feature in the author's stratigraphical summary is that he does not accept the occurrence of any Devonian or Carboniferous rocks in New Zealand. The Maitai series he regards as Triassic, and perhaps partly Jurassic. No doubt much of the Maitai belongs to those two systems, but Prof. Marshall offers no adequate explanation of the presence of Carboniferous brachiopods in these rocks. That the Maitai includes some Carboniferous strata still seems the safest conclusion.

The author states that " too much attention has been paid in the past to the palæontological evidence" (p. 197). No such complaint could be made against this book, for it omits reference to the palæontological evidence which controls the correlation of some New Zealand rocks.

The work begins with an interesting summary of the physical features of the 
ocean floor in the New Zealand area, and the sketch-map brings out the fundamental importance of the ridges running from north-north-east to south-southwest, from Samoa to New Zealand and along it, and of another series at right angles to the first, including the long north-western peninsula of the north island.

As Dr. Marshall is an expert petrographer, his account of the varied igneous rocks of New Zealand will be read with special interest. It is worthy of note that he concludes that no effects of petrographic differentiation have yet been recognized in New Zealand. He adopts the view that most of the water which escapes from the hot springs is of "juvenile" origin, and dismisses its supposed origin from rain-water, a view which he remarks has "yet some supporters" (p. 114).

The book is issued by the Minister of Education in New Zealand. Among its many valuable contributions is an excellent coloured geological map of New Zealand, which will replace the long-used map by Hector.

\section{MATHEMATICAL AND PHYSICAL GEOGRAPHY.}

$$
\text { J. W. G. }
$$

Valley Steps.

'Taltreppe. Eine Geologisch-Geographische Darstelling.' Von V. Hilber, Professor an der Universität in Graz. Graz: Deutsche Vereins-Druckerei. 1912. A map and three views. Pp. 50. Price M.2.50.

By the term Taltreppe the author denotes the series of terraces and shelves in a valley, whether longitudinal or transverse. He describes twelve such terraces in the neighbourhood of Graz, six of which he assigns to the Tertiary age, while five are of diluvial origin and one of alluvial. They range from a height of 1150 feet up to 4720 feet. The causes of the formation of the terraces of accumulation, Baustufen in Prof. Hilber's nomenclature, and erosion terraces, Grundstufen, are fully described, and the period of their origin is discussed. No small part of the book is occupied with controversial matter, the views of Profs. Penck and Brückner being the object of attack. Prof. Penck ('Die Alpen in Eiszeitalter') has found that the terraces in Alpine valleys very frequently adjoin terminal moraines, and are dovetailed into them, and must therefore be of the same age. Valley terraces, however, occur in countries which have never been glaciated, and Prof. Hilber has found terraces below moraines consisting entirely of water-worn pebbles, while Böhm and Heritsch speak of moraines overlying the terrace pebbles. If, however, his opponents refer only to the fans immediately below the moraines, Prof. Hilber does not dispute the glacial origin of their material. He also differs from the two professors as to the time when the terraces were formed. $\mathrm{He}$ has found large accumulations of detritus dating from the Pliocene age, and holds that the diluvial terraces were more probably formed in interglacial prriods rathrr than in glacial periods, when the greater rainfall would swell the rivers and carry off the detritus, whereas Prof. Penck holds that when glaciers reached their greatest extension erosion was greater and the rivers deposited their load. Other subsidiary questions are also discussed.

\section{Plant Geography.}

'An Introduction to Plant Geography.' By M. E. Hardy, D.sc. Pp. $192 . \quad$ Oxford: Clarendon Press. 1913. Maps and Illustrations. 2s.6d.

This latest volume of the Oxford Geographies is very welcome. No one could be better qualified than Dr. Hardy to write such a volume, and its want was much felt by teachers. At the basis of all human geography must always lie the study 